\title{
THE EDUCATION AND LANGUAGE OF INDIGENOUS PEOPLES OF THE NORTHERN TYUMEN REGION: AN ANALYSIS OF TENDENCIES AND DEVELOPMENT PERSPECTIVES
}

\author{
Nursafa Gafurovna Khairullina', Thaiany Pedrozo Campos Antunes², Anna Borisovna Fokina ${ }^{3}$
}

DOI: http://dx.doi.org/10.7322/jhgd.106016

\begin{abstract}
Introduction: national education and native language are potential points of safety and development for indigenous small-numbered peoples. Objective: to analyze the tendencies in the field of native language and national education of indigenous small-numbered peoples of the Northern Tyumen region. Methods: descriptive and retrospective analysis of sociological monitoring was conducted from 1993 to 2011 over two-year intervals to reveal indigenous peoples' problems. Results: in 1993, 35\% of indigenous small-numbered peoples of the Northern Tyumen region noted that they had mastered the native language, while only $24 \%$ did not master the language. Whereas towards 2011 , only $6 \%$ of these peoples had mastered their native language and $65 \%$ had not mastered the language. At the end of our research, in 2011, an absolute majority of respondent indigenous peoples noted the need for lessons of their native language, $70 \%$ study in Russian language and $30 \%$ would like to study the native language. Conclusion: there is a tendency of the indigenous small-numbered peoples of the Northern Tyumen region to assimilate their native language and they have a high interest in having their native language included as a component of national education.
\end{abstract}

Keywords: indigenous people, education, native language.

\section{INTRODUCTION}

It is emphasized in the article of the British magazine The Economist that the indigenous smallnumbered peoples of the north (ISPN) of Tyumen region have to resist many modern threats when their cultural traditions are not only being destroyed but also washed off by. ${ }^{1}$ The processes of assimilation and the loss of original culture of smallnumbered ethnic populations all over the world, including the indigenous peoples of Northern Tyumen region.

Tyumen region is one of the biggest regions of the Russian Federation (RF). Its territory occupies the third largest place in the RF and it makes up more than 1,4 million $\mathrm{km}^{2}$ ( $8.4 \%$ of Russia). The region has a multinational population with representatives of more than 140 nationalities living there, including 26 indigenous peoples of the north. The number of indigenous peoples of the north living in this district makes up 67 thousand people, or one third of their total number in the Russian Federation. ${ }^{2}$ The greatest number of representatives of four indigenous peoples (90\% Khanty, 95\% Mansi, 65\% Nenets, $45 \%$ Selkups) is concentrated within the bounds of Tyumen region. There are preserved groups with a sufficiently strong traditional and cultural potential - yamalskaya, polar ural, gydansky, tazovskaya groups of nomadic tundra Nenets, numtinsko-purovskaya group of wood Nenets, voikarskaya, synskaya, kunovatskaya, kazymskaya group of Khanty, sosvinsko-lyapinskaya group of mansy, verkhne-tazovskaya group of selkups - within the bounds of Tyumen region in the environment of the four mentioned peoples.

This study into the problems of the ISPN is determined firstly by the special role of these ethnicities in the social and cultural heritage of humanity; secondly, by changes in the environment of these peoples; and thirdly, by the processes

1 Sociology academic department, Tyumen state oil and gas university, Tyumen, RF.

2 Laboratório de Delineamento de Estudo e Escrita Científica da Faculdade de Medicina do ABC.

3 Marketing and municipal management academic department, Tyumen state oil and gas university, Tyumen, RF. Corresponding author: Anna Borisovna Fokina E-mail: fannabor@bk.ru

Suggested citation: Khairullina NG, Antunes TPC, Forkina AB. The education and language of indigenous peoples of the Northern Tyumen region: An analysis of tendencies and development perspectives. Journal of Human Growth and Development. 25 (3): $371-376$. Doi: http://dx.doi.org/10.7322/jhgd.106016

Manuscript submitted Oct 22 2014, accepted for publication Dec 192014. 
occurring in the modern world that affect their interests.

The study represents a scientific interest to investigate the reasons for the problems, providing perspectives and formulating recommendations on the one hand, for preserving ethnocultural originality and, on the other hand, for the development of both ISPN of Tyumen region and other small-numbered ethnicities of the world. Therefore, the aim of this study is to analyze, using explanations and illustrations, tendencies in the field of native language and education of the indigenous small-numbered peoples of Northern Tyumen region, in order to discover perspectives for potential development.

\section{METHODS}

This study was based on the materials of longstanding surveys of the daily living habits of the ISPN of Tyumen district, the results of which are in the scientific works by N. G. Khairullina, T. G. Haramzin, S. N. Haryuchi, G. P. Haryuchi and A. A. Yuzhakov. ${ }^{2-7}$
From 1993 to 2011, we surveyed 5500 ISPN individuals. The individuals came from indigenous populations in centres of national and subnational entities, and from communities of compact living for indigenous inhabitants of Khanty-Mansi Autonomous Okrug, situated in the Northern Siberian region in the Northern Tyumen region; that is, Beloyarsky, Berezovsky, Oktyabrsky and Kondinsky districts.

We used sociological monitoring (from 1993 to 2011) through a multiple-choice questionnaire on language preferences and the weaknesses of national school education (table 1). Initially, the questionnaire was composed only of its first question. It was applied at 1993, 1995 and 1997. After that, we found the need to record in detail the study of language processes and more questions were added. A section of the questions was repeated every two years, allowing the analysis of dynamics and tendencies. The period of two years between the surveys was not chosen randomly, as this interval allowed the researchers to form a picture and analyze occurring changes, and the dynamics of the education and language of the ISPN population of the Northern Tyumen region.

Table 1. Questionnaire on language preferences and the weaknesses of national school education (translated into English Language)

\begin{tabular}{|c|c|c|c|c|c|c|}
\hline \multirow[b]{2}{*}{1} & \multirow{2}{*}{$\begin{array}{l}\text { Question } \\
\text { What is your level of } \\
\text { native language? }\end{array}$} & \multicolumn{5}{|c|}{ Multiple Choices } \\
\hline & & master it freely & speal & $\mathrm{k}$ and can read & only speach & $\begin{array}{l}\text { do not master the } \\
\text { language }\end{array}$ \\
\hline 2 & $\begin{array}{l}\text { What language do } \\
\text { you know best? }\end{array}$ & native & & Russian & & both native and Russian \\
\hline 3 & $\begin{array}{l}\text { What language do } \\
\text { you speak at home? }\end{array}$ & native & & Russian & & both native and Russian \\
\hline 4 & $\begin{array}{l}\text { What language do } \\
\text { you speak at work } \\
\text { native }\end{array}$ & native & & Russian & & both native and Russian \\
\hline 5 & $\begin{array}{l}\text { What language did } \\
\text { you speak at } \\
\text { childhood? }\end{array}$ & native & & Russian & & both native and Russian \\
\hline 6 & $\begin{array}{l}\text { What are weaknesses } \\
\text { the school education } \\
\text { have? }\end{array}$ & $\begin{array}{l}\text { does not } \\
\text { provide } \\
\text { sufficient } \\
\text { general } \\
\text { knowledge } \\
\text { including } \\
\text { admission to } \\
\text { colleges, } \\
\text { elementary } \\
\text { vocational } \\
\text { training }\end{array}$ & $\begin{array}{l}\text { often } \\
\text { provides } \\
\text { superfluous } \\
\text { knowledge } \\
\text { and does } \\
\text { not teach } \\
\text { things that } \\
\text { are } \\
\text { necessary } \\
\text { for living in } \\
\text { the North }\end{array}$ & $\begin{array}{l}\text { health of } \\
\text { children } \\
\text { declines }\end{array}$ & $\begin{array}{l}\text { a child } \\
\text { separates } \\
\text { from family }\end{array}$ & $\begin{array}{ll}\text { children does } & \text { does not provide } \\
\text { not learn } & \text { sufficient } \\
\text { history of their } & \begin{array}{l}\text { knowledge of } \\
\text { nation, }\end{array} \\
\begin{array}{l}\text { native language } \\
\text { culture and }\end{array} & \end{array}$ \\
\hline 7 & $\begin{array}{l}\text { What teacher's } \\
\text { nationality do you } \\
\text { prefer? }\end{array}$ & $\begin{array}{l}\text { success of teach } \\
\text { training of a tea } \\
\text { nationality }\end{array}$ & $\begin{array}{l}\text { ng is in } \\
\text { her, not his }\end{array}$ & $\begin{array}{l}\text { best skilled wc } \\
\text { Russian teach } \\
\text { knowledge of } \\
\text { traditions and } \\
\text { aboriginal inh }\end{array}$ & $\begin{array}{l}\text { rkers are } \\
\text { rs that have } \\
\text { ational } \\
\text { Nay of life of } \\
\text { bitants }\end{array}$ & $\begin{array}{l}\text { would like to have as teachers of } \\
\text { their children only people of the } \\
\text { same nationality }\end{array}$ \\
\hline 8 & $\begin{array}{l}\text { Is history study of } \\
\text { the nation important? }\end{array}$ & it is an essential & task of school & $\begin{array}{l}\text { it is a necessa } \\
\text { school educati }\end{array}$ & $\begin{array}{l}\text { y element of } \\
\text { on }\end{array}$ & $\begin{array}{l}\text { in comprehensive school, it is } \\
\text { unnecessary }\end{array}$ \\
\hline 9 & $\begin{array}{l}\text { Your opinion } \\
\text { concerning native } \\
\text { language at school }\end{array}$ & lessons of native & language & study in Russi & n language & study in native language \\
\hline
\end{tabular}

The situation in the field of education was analyzed according to the results of the questionnaire from 2011.
We used survey materials from modern scientists and experts on the problems of tradition preservation, security of social and cultural 
development and the increase of the educational levels of ISPN of the Northern Tyumen region, world educational tendencies. ${ }^{8-16}$

The data collected were grouped into IBM SPSS Statistics 22 software to conduct the calculations of means, percentage, and correlations. A correlation analysis was done; firstly, between 'language knowledge level' and 'sphere of work', secondly, between 'ISPN language spoken at home' and 'age'. The result was expressed as percentages.

The main sample calculation principle was the proportionality of observation units: sex, age, education, career. The sample is $8 \%$ of the general population, reflecting an adequate sample of the socio-demographic structure of the ISPN population of the Northern Tyumen region. That is, it suggests that the results are representative.

\section{RESULTS}

Language of indigenous small-numbered peoples of the Northern Tyumen region

Between 1993 and 2011, the dynamics of the level of knowledge of native languages was explored among the ISPN using the questionnaire form (Figure 1).
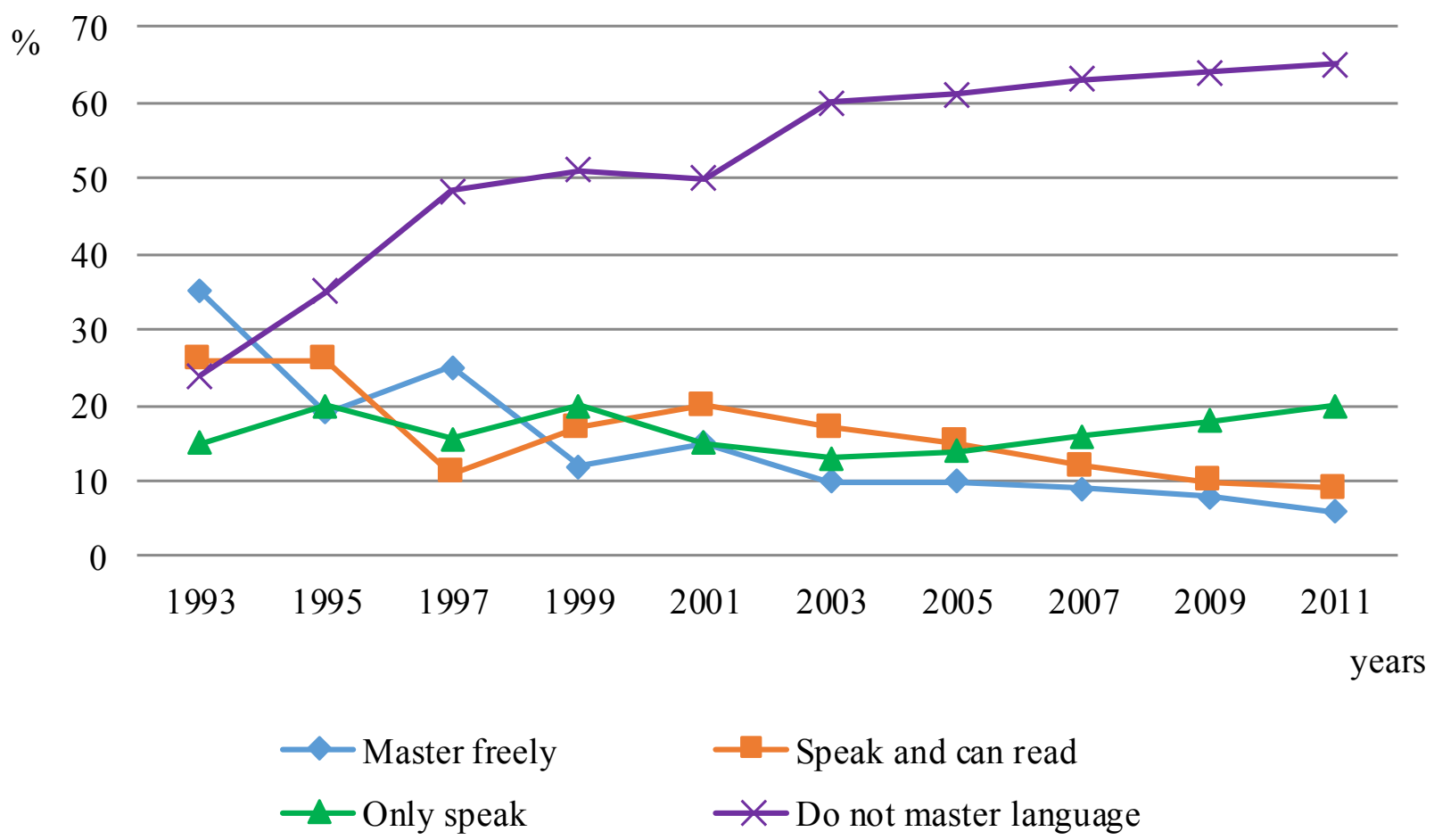

Figure 1: Dynamics of knowledge levels of native language of ISPN, shown in percentage of total number of respondents

The tendencies of the language processes are shown in Table 2.

Table 2: Dynamics of answers from ISPN about language knowledge, shown in percentage of total number of respondents

\begin{tabular}{|c|c|c|c|c|c|c|c|c|c|c|c|c|c|c|c|c|c|c|c|c|c|}
\hline \multirow[t]{2}{*}{ Question } & \multicolumn{7}{|c|}{ Native } & \multicolumn{7}{|c|}{$\begin{array}{c}\text { Language } \\
\text { Russian }\end{array}$} & \multicolumn{7}{|c|}{ Both native and Russian } \\
\hline & 999 & 001 & 003 & 005 & 007 & 009 & 011 & 999 & 001 & 003 & 005 & 007 & 009 & 011 & 999 & 001 & 003 & 005 & 007 & 009 & 011 \\
\hline $\begin{array}{c}\text { Language you } \\
\text { know best } \\
\text { of all }\end{array}$ & 2 & 5 & 0 & 7.9 & 3 & 6 & 2.9 & 8 & 0 & 0 & 9.1 & 1 & 4 & 5.2 & 0 & 5 & 0 & 3 & 6 & 0 & 1.9 \\
\hline $\begin{array}{c}\text { Language you } \\
\text { Speach at } \\
\text { home }\end{array}$ & 0 & 0 & & 1 & & 1 & 9 & 7 & 0 & 1 & 5.2 & 6 & 7 & 77 & 3 & 0 & 0 & 6.7 & 7 & 6.9 & 4.4 \\
\hline $\begin{array}{c}\text { speak at work } \\
\text { Speach at } \\
\text { work }\end{array}$ & & & & .1 & & .5 & .3 & 0 & 2 & 5 & 8.6 & 9 & 0 & 2.6 & & & 2 & 8.3 & 9 & 8.5 & 6.1 \\
\hline $\begin{array}{c}\text { Language you } \\
\text { spoke at } \\
\text { childhood }\end{array}$ & 0 & 4 & 7 & 9 & 0 & 5 & 5.8 & 9 & 0 & 7 & 5 & 3 & 5 & 8.4 & 1 & 6 & 6 & 6 & 7 & 0 & 5.8 \\
\hline
\end{tabular}

The structure of answers to the question "What language do you know best of all?" is shown in Table 3 . 
Table 3: Answers to the question "What language do you know best of all?" according to sector of employment, shown in percentage of total number of respondents

$\begin{array}{lcccc}\text { Sector of employment } & \text { Native } & \begin{array}{c}\text { Language } \\ \text { Russian }\end{array} & \begin{array}{c}\text { Both native } \\ \text { and Russian }\end{array} & \text { Total } \\ \text { Traditional nature management } & 90.7 & 5.3 & 4 & 100 \\ \text { Petroleum industry } & 30 & 30 & 40 & 100 \\ \text { Service } & 70 & 10 & 20 & 100 \\ \text { Education } & 75 & 17 & 8 & 100 \\ \text { Culture } & 50 & 15 & 35 & 100 \\ \text { Public health (service) } & 36 & 27 & 37 & 100 \\ \text { Communication } & 42 & 31 & 27 & 100 \\ \text { Bodies of power } & 25 & 30 & 35 & 100 \\ \text { Transport } & 39 & 26 & 44 & 100 \\ \text { Building } & 47 & 9 & 12 & 100 \\ \text { Unemployed } & 85 & 3 & & 100\end{array}$

The more people there are of old age groups within an aboriginal population, the more people there are that master the language. This tendency is illustrated in Table 4.

Table 4: Answers to the question "What language do you speak at home?" according to age, shown in percentage of total number of respondents.

$\begin{array}{cccccccc}\text { Language } & \mathbf{2 0} & \mathbf{2 1 - 3 0} & \mathbf{3 1 - 4 0} & \mathbf{4 1 - 5 0} & \mathbf{5 1 - 6 0} & \boldsymbol{>} \mathbf{6 1} & \text { Total } \\ \text { Native } & 0 & 7.7 & 30.8 & 15.4 & 38.5 & 7.6 & 100 \\ \text { Russian } & 19.2 & 30.8 & 21.1 & 18.3 & 9.6 & 1 & 100 \\ \text { Both native } & 2.4 & 21.4 & 23.8 & 31 & 19.1 & 2.3 & 100 \\ \text { and Russian } & & & & & \end{array}$

Development of ISPN of Northern Tyumen region

It is important to remark that in every second national settlement there are no national schools and, in particular, in $67 \%$ of comprehensive schools there are no courses of national language study.

With regard to the question concerning the main weaknesses of school education, the following answers were obtained:

School does not provide sufficient general knowledge, including about admission to colleges, elementary vocational trainings and higher school $-53.3 \%$
School often provides superfluous knowledge but does not teach things that are necessary for living in the Northern Tyumen region - 50\%;

The health of children declines - 40\%;

Children are separated from their families-28.2\%;

Children do not learn the history of their nation, customs and culture $-69.4 \%$;

School does not provide sufficient knowledge of native language $-63.5 \%$.

One third of aboriginal inhabitants site the importance of full national autonomy in the teaching system (Figure 2).
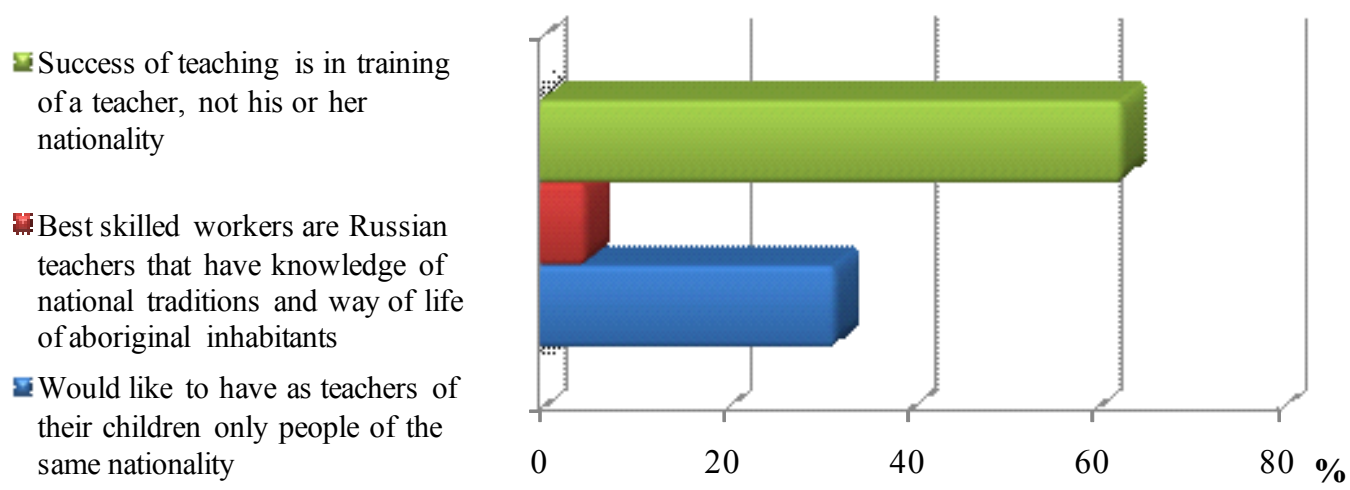

Figure 2: Answers of the ISPN about the teacher nationality, shown in percentage of total number of respondents. 
Fifty-two per cent of respondents considered study of the history of the nation to be an essential task at school and $20.1 \%$ considered it to be a necessary element of school education. Only $3.4 \%$ considered study of the history of the nation in comprehensive school to be unnecessary.

Although a small part of children have the lessons taught originally in their native language, all of them have native language lessons (figure 3).

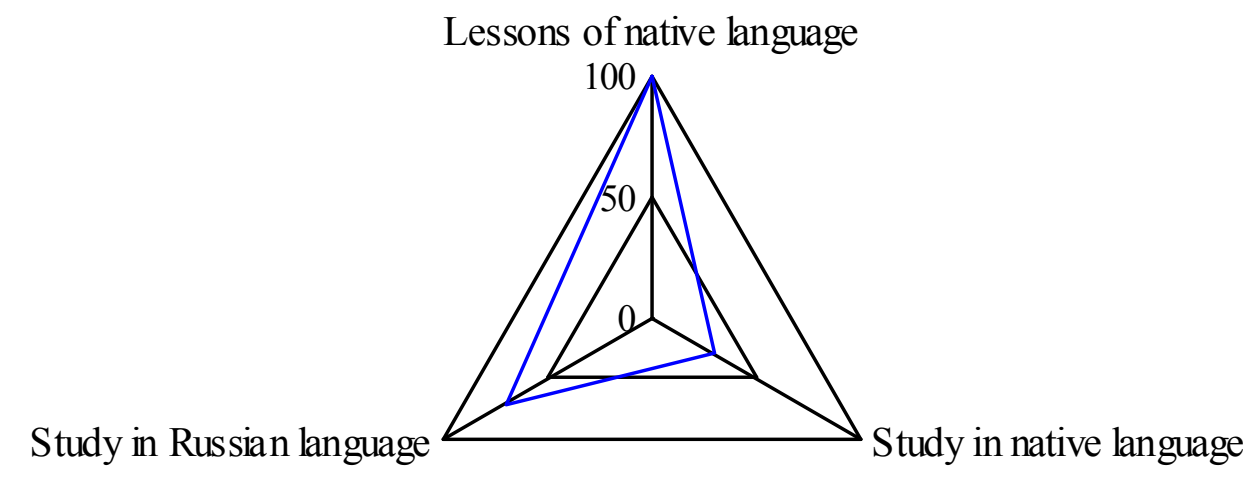

Figure 3: Language taught at school for ISPN, shown in percentage of total number of respondents

Thus, it is important to remark that the absolute majority of respondent ISPN noted the study of native language in all classes of comprehensive school to be necessary. A third even claimed that all teaching should be conducted in native language (Khairullina, 2012). ISPN could choose several choices of this question-indicator.

\section{DISCUSSION}

A critical objective of this study was to analyze materials of sociological monitoring with explanations and illustrations in order to discover the language and education perspectives of ISPN. For this, we analyzed tendencies in the field of native language and national education of indigenous small-numbered peoples of the Northern Tyumen region.

We could observe that the sector of employment is one of the factors that may or may not stimulate native language competence levels. Respondents employed in traditional branches of the northern trade economy and education sector of employment had the highest level of native language knowing.

Furthermore, most representatives of ISPN in the Northern Tyumen region had no knowledge of their mother tongue. One reason for this is that teaching in schools was conducted in the Russian language. In addition, both the quantity and quality of native language courses in the Northern Tyumen region schools are low.

Besides, there has been remarked the tendency of decreasing of the amount of respondents who can speak and read in the native language with the simultaneous increasing of the amount of respondents who can only speak. The tendency of an increasing interest in learning the mother language appears to be encouraging.

Concerning education, it is important to remark that the education system for the ISPN in the Tyumen region is not notable for high efficiency. This is has some reasons: the predominance of visual thinking, the qualitative change from the cultural and objective environment of the preschool period during the formation of personalities, and the active character of traditional forms of teaching and culture reproduction are not considered ${ }^{13}$. However, the materials and objects used as a support to children's recreational activities are important references to understand the symbolic dialogue between children and their social group (thus, they are directly related to the socio-cultural reality around them), and to better understand children's play culture. As a suggestion, this could be used to introduce the maternal language during childhood. ${ }^{17}$

Most respondents stated they would teach their children native language and offered the opinion that it is necessary to teach it at schools. Developing such education would take into account national peculiarities of ethnic groups. increasing the level of native language knowledge, which would strengthen ethnic self-awareness. This is especially important because language is the base of national culture.

Supported by Culture Psychology, a study conducted in an agricultural community in the city of Caeté, in the state of Minas Gerais (Brazil)18, aimed to understand the principles of an educational practice that 'rescues' popular culture in the school setting as a way to contribute to the consideration of the nexus between education and culture. This community was chosen because it is known for the vitality of its traditions. The study found two main motivations for making popular culture a mandatory source of education: a) to take care of the culture that one recognizes as a part of oneself; b) to foster children's participation in culture as a way of taking care of their present and future. This confirms the importance of the educators in the revival of the relationship between school education and popular culture. It is the personal acknowledgement of the rootedness in the tradition of which one is an heir that allows one to act, favouring both the strengthening of culture and the recovery of the legitimacy of educational practice that takes place at the scholastic institution. ${ }^{18}$ 
Teaching native language and culture at schools might provide a harmonious integration of ISPN in the modern world community against the background of discovered tendencies, and also support the intention of the world community to preserve traditional cultures of small-numbered ethnicities. One cannot but remark that figured author's position does not contradict the views of authoritative Russian scientists who have surveyed the problems of small-numbered ethnic groups. ${ }^{9}$ 11-14, 16 In addition, the nation itself should choose the further vector of development of education and language processes.

\section{CONCLUSION}

There is a tendency of the indigenous smallnumbered peoples of Northern Tyumen to assimilate their native language and they have a high interest in having their native language included as a component of national education.

\section{REFERENCES}

1. Special report. The Melting North. The Economist. [cited 2012 June 16] Available from: http://www.economist.com/node/21556798 Haramzin TG, Khairullin NG. The monitoring of Ob ugry social well-being. Saint-Petersburg: 2006.

2. Haryuchi SN, Haryuchi G P, Yuzhakov A A. Khairullina NG. Yamal Nenets: nomads and traditions nurses. Tyumen-Salehard: Felix; 2005.

3. Khairullina NG. Balyuk NA. The reconstruction of traditional ecosystem exploitation of Ob Ugry. Tyumen: TyumGNGU; 2007.

4. Haramzin TG, Khairullina NG. The traditional practice and mode of life of Ob Ugry (based on materials of sociological surveys). IKAR; 2002.

5. Haramzin TG, Khairullina NG. The social and economical development of Ob Ugry on the stage of changeover to exchange relations. Khanty-Mansiysk: GUIPP "Polygraphist"; 1998.

6. Khairullina NG. The indigenous peoples of the Tyumen district: sociologist view. Tyumen: Tyum GNGU; 2012.

7. Fokina $A B$. The educational preferences of ethnical population: the dynamics of surveys. News from higher educational institutions. Sociol Economics Politics. 2014(2):74-77.

8. Popkov, Y.V. Indigenous Peoples of the North in the Context of Globalization. Age of globalization. J Global Studies. 2014; 6(1): 111-123.

9. Assao TY, Westphal MF, Bógus CM, Lara BR, AMancuso AMC. School feeding: what children's drawings reveal. J Human Growth Dev. 2014;24(1): 98-105.

10. Popkov YV, Tyugashev EA. Ethnosocial processes in Siberia: modern reality and actual issues of ethnosocial policies. New Surv Tuva. 2014; 3(23): 136-151.

11. Markhinin VV, Udalova IV. Indigenous peoples of Yugra in interethnic relations. Vestnik Novosibirsk state university. Series: Philosophy. 2012a; p.56-63.

12. Markhinin VV, Udalova IV. Russians and indigenous peoples of the North: risks for future ethoses (based on opinion polls in yugra. 19912011). Vestnik Novosibirsk state university. Series: Philosophy. 2012; p. 110-119.

13. Lamazhaa CK. The Archaization of Society in the Period of Social Transformations, Knowledge Understanding, Skill. 2011; p. 35-42.

14. Corrêa LS, Cavalcante LIC. Shelter educators: conceptions on development and care practices in play situation. J Human Growth Dev. 2013; 23(3): 309-17.

15. Lamazhaa CK. Social Transformation, Knowledge, Understanding, Skill. 2011; p.262-264.

\section{Resumo}

Introdução: a educação nacional e língua nativa são potenciais pontos de segurança e desenvolvimento para os pequenos povos indígenas. Objetivo: analisar as tendências no domínio da língua materna e da educação nacional dos pequenos povos indígenas da região Norte de Tyumen, na Rússia. Método: foi realizada uma análise sociológica descritiva e retrospectiva entre 1993 e 2011, em intervalos de dois anos. Resultado: em 1993, 35\% dos pequenos povos indígenas da região Norte de Tyumen observaram que tinham domínio da língua nativa, enquanto apenas $24 \%$ não dominavam a língua. Em 2011, apenas 6\% desses povos dominavam sua língua nativa e $65 \%$ não dominavam. Ao final da pesquisa, em 2011, a maioria absoluta dos povos indígenas estudados referiram a necessidade de lições de sua língua nativa. $70 \%$ dessa população estudava no idioma russo e os outros 30\% gostariam de estudar em sua língua nativa. Conclusão: há uma tendência dos pequenos povos indígenas da região Norte de Tyumen em assimilar sua língua nativa e eles têm grande interesse em ter seu idioma nativo incluído como um componente da educação nacional.

Palavras-chave: povo indígena, educação, linguagem nativa. 